\title{
CYTOKINESIS-BLOCK MICRONUCLEUS ASSAY IN HUMAN GLIOMA CELLS EXPOSED TO RADIATION
}

\author{
JERZY SLOWINSKI ${ }^{1}$, GRAZYNA BIERZYNSKA-MACYSZYN² ${ }^{2}$ URSZULA MAZUREK $^{3}$,

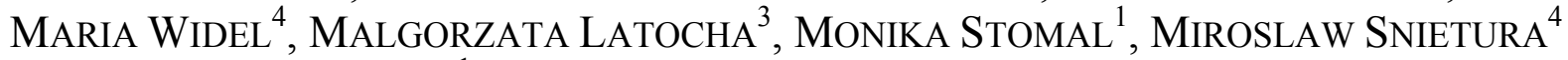 \\ AND RYSZARD MROWKA ${ }^{1}$
}

${ }^{1}$ Department of Neurosurgery and Neurotraumatology, Medical University of Silesia, Al. Legionow 10, 41-902 Bytom, Poland, ${ }^{2}$ Department of Pathology, Medical University of Silesia, Medykow 18, 40-752 Katowice, Poland, ${ }^{3}$ Department of Molecular Biology, Biochemistry and Biopharmacy, Medical University of Silesia, Narcyzow 1, 41-206, Sosnowiec, Poland, ${ }^{4}$ Department of Radiobiology, Center of Oncology, Wybrzeze Armii Krajowej 15, 44-100 Gliwice, Poland

e-mail: slowian@mp.pl,rmrowka@mp.pl,macyszyn@wp.pl, umazurek@slam.katowice.pl, mlatocha@slam.katowice.pl,widel@io.gliwice.pl

(Accepted April 26, 2004)

\begin{abstract}
Biological tests are efficient in reflecting the biological influences of several types of generally harmful exposures. The micronucleus assay is widely used in genotoxicity studies or studies on genomic damage in general. We present methodological aspects of cytokinesis-block micronucleus assay performed in human gliomas irradiated in vitro. Eight human glioblastoma cell lines obtained from DSMZ (Deutsche Sammlung von Mikroorganismen und Zellkulturen $\mathrm{GmbH}$, Germany) were gamma-irradiated $\left({ }^{60} \mathrm{Co}\right)$ over a dose range of 0-10 Gy. Cytokinesis-block micronucleus assay was performed to quantitate cytogenetic damage. The cells were fixed directly on dishes, stained with fluorochrome DAPI and evaluated under fluorescent and phase contrast microscope. The micronucleus frequency was expressed as a micronuclei (MN) per binucleated cell (BNC) ratio, calculated after scoring at least $100 \mathrm{BNC}$ per dish. The frequency of spontaneous $\mathrm{MN}$ ranged from 0.17 to 0.613 (mean: $0.29 \pm 0.14$ ). After irradiation increase of $\mathrm{MN}$ frequency in the range of $0.312-2.241$ (mean: $0.98 \pm 0.68$ ) was found at $10 \mathrm{~Gy}$. Gliomas are extremely heterogenous in regard to cytogenetic effects of irradiation, as shown in this study by cytokinesis-block micronucleus assay. This test is easily performed on irradiated glioma cell lines and can assist in determining their radiosensitivity. However, in order to obtain reliable and reproducible results, precise criteria for $\mathrm{MN}$ scoring must be strictly followed. Simultaneous use of fluorescent and phase contrast equipment improves imaging of morphological details and can further optimize MN scoring.
\end{abstract}

Keywords: glioma, micronucleus assay, radiosensitivity.

\section{INTRODUCTION}

The cytogenetic assay of micronuclei was established almost thirty years ago (Schmid, 1975). Cytokinesis-block was introduced to micronucleus assay by Fenech and Morley $(1985,1986)$. Micronuclei $(\mathrm{MN})$ are structures that arise from acentric chromosome fragments or complete chromosomes that failed to attach to mitotic spindle during cytokinesis and are excluded from the daughter nuclei into the cytoplasm (Weissenborn and Streffer, 1992; Fuhrmann et al., 1992). MN represent structural chromosomal aberrations (chromosome loss or breakage) induced by ionizing radiation or chemical mutagens (Fenech, 2000). Micronuclei can be measured after DNA staining by the Feulgen reaction, Giemsa or fluore- scence dyes. Evaluation of micronucleus frequency is widely used for determination of cellular radiosensitivity (Wandl et al., 1989; Shibamoto et al., 1991, Widel et al., 2001; 2003). Generally, radiosensitive cells are more susceptible to radiation-induced micronucleus formation. In the previous study, performed by one of the authors (MW), usefulness of cytokinesisblock micronucleus (CBMN) assay in evaluating radiosensitivity of malignant melanoma was proved (Widel et al., 1997). Human gliomas, like melanomas, are very heterogeneous tumours in regard to their response to radiotherapy. This prompted us to validate applicability of CBMN assay in irradiated human glioma cell lines and to discuss some methodological aspects related to scoring $\mathrm{MN}$ in vitro. The test may allow the grouping of gliomas in terms of sensitivity to 
radiation and to identify tumours with favourable response after radiation treatment.

\section{MATERIALS AND METHODS}

\section{CELL CULTURE AND IRRADIATION}

Eight human glioma cell lines (42-MG-BA, DBTRG-05-MG, DK-MG, GAMG, GOS-3, LN-405, 8-MG-BA and U-138-MG) were purchased from DSMZ (Deutsche Sammlung von Mikroorganismen und Zellkulturen $\mathrm{GmbH}$, Braunschweig, Germany) (Drexler et al., 2001). Cells were cultured as monolayers in Easy Y Flasks (Nunc) in DMEM or RPMI medium (according to the manufacturer's recommendations), supplemented with $10 \%$ fetal bovine serum and 100 units/ml penicillin and 100 $\mu \mathrm{g} / \mathrm{ml}$ streptomycin at $37^{\circ} \mathrm{C}$, in a humid atmosphere of $5 \% \mathrm{CO}_{2} / 95 \%$ air. The cultures were trypsinized and plated $\left(3-5 \times 10^{5}\right.$ cells per plate $)$ into $50 \mathrm{~mm}$ plastic culture dishes (Nunc) in $5 \mathrm{ml}$ of growth medium. After $24 \mathrm{hrs}$ (time required for cell attachment) the cells were irradiated in culture dishes using Philips ${ }^{60} \mathrm{Co} \gamma$-ray unit at a dose rate 0.8 $\mathrm{Gy} / \mathrm{min}$, at room temperature to a total dose of $0,2,4$, 6, 8 and 10 Gy. The control (non-irradiated) cells were sham exposed for the same period. For subsequent irradiation at a given dose each culture was plated into three dishes, so the data of individual cell lines were pooled as triplicates.

\section{MICRONUCLEUS ASSAY}

CBMN assay with cytokinesis-block induced by cytochalasin B was performed according to the method described by Shibamoto et al. (1991) and Fuhrmann et al. (1992), with minor modifications. Cytochalasin B is used to inhibit the cell division after mitosis. This leads to cells which contain two nuclei, and micronuclei, if chromosome breaks have occurred or the centromere is damaged. Immediately after irradiation the cells were treated with cytochalasin B (Sigma), dissolved in dimethylosulfoxide to a final concentration of $2 \mu \mathrm{g} / \mathrm{ml}$. After $72 \mathrm{~h}$ incubation the cells were fixed in cold $\left(-20^{\circ} \mathrm{C}\right)$ ethanol $96^{\circ}$ for $15 \mathrm{~min}$, washed with distilled water, re-fixed in acetic acid:methanol $(1: 3 \mathrm{v} / \mathrm{v})$ for $15 \mathrm{~min}$ and washed. The fixed cells were stained with a drop of fluorochrome DAPI (4',6'-diamidino-2-phenylindole $\mathrm{HCl}$, Serva), dissolved in Tris-buffer $(\mathrm{pH}$ 7.5) at a $2 \mu \mathrm{g} / \mathrm{ml}$ concentration. The control (non-irradiated) cells were also incubated with cytochalasin B.

\section{MICROSCOPIC EVALUATION AND MN SCORING}

The preparations were evaluated under photomicroscope Axiophot (Zeiss, Germany), equipped with fluorescence illuminator (HBO50 lamp) and the filter set for $365 \mathrm{~nm}$ excitation and $420 \mathrm{~nm}$ emission wave length (specific for fluorochrome DAPI). The phase contrast equipment was also used. Analysis was performed at magnification $\times 400$. To facilitate discrimination of $\mathrm{MN}$ and differentiation between mononucleated, binucleated (which divided once after irradiation) and polynucleated cells (which divided twice or more), the phase contrast was used together with fluorescent microscopy. Microscopic analysis was performed by one observer (MW), excluding the possibility of determining interobserver variability, where a series of preparations was viewed by a second experienced observer. Scoring was performed blindly. The percentage of binucleated cells $(\% \mathrm{BNC})$ per dish was evaluated after scoring 1000 consecutive cells distributed as a monolayer. The BNC were selected according to criteria described by Fenech et al. (2003). The apoptotic and necrotic cells were included in the total cell number, however micronuclei were not scored in these cells. The number of $\mathrm{MN}$ in at least $100 \mathrm{BNC}$ was scored according to the criteria of Countryman and Heddle (1976), Fenech and Morley (1985), Falkvoll (1990) and Fenech et al. (2003), and the $\mathrm{MN} / \mathrm{BNC}$ ratio was calculated. The round or oval, non-refractile bodies detached from the nucleus, smooth-outlined and with a diameter not greater than one-third the large diameter of the main nuclei were considered as MN. Only MN separated from the main nucleus and just touching but not overlapping the main nucleus were scored. The experimental data presented in Table 1 and Fig. 1 are the mean values from 3 independent dishes per experimental point. The MN frequency in control (non-irradiated) cells, representing so-called spontaneous $\mathrm{MN}$ was regarded as a baseline level. The percentage of binucleated cells $(\% \mathrm{BNC})$ in non-irradiated cells was used for measurement of proliferation fraction in vitro (Widel et al., 2001). 

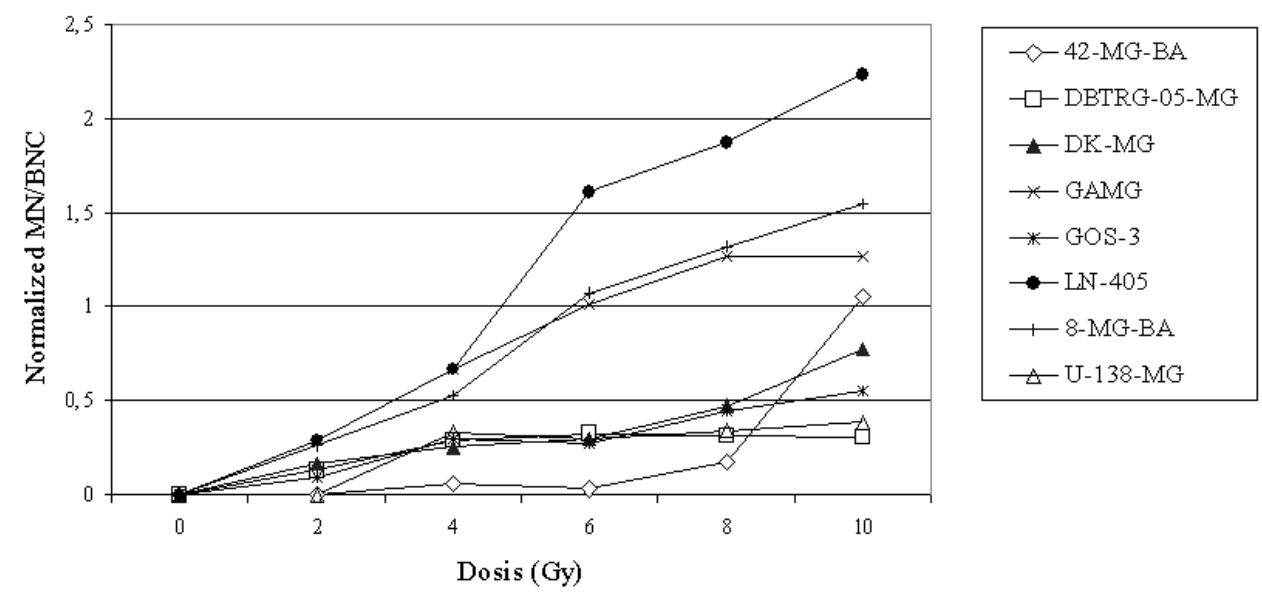

Fig. 1. Normalized micronuclei per binucleated cell (MN/BNC) ratio in irradiated human glioma cell lines. A dose dependent increase in micronuclei frequency and relative radioresistance of most cell lines is seen.

Table 1. Percentage of binucleated cells and absolute values of micronuclei per binucleated cell ratio in eight human glioma cell lines after gamma-irradiation.

\begin{tabular}{|l|r|r|r|r|r|r|r|r|r|r|r|r|}
\hline \multicolumn{1}{|c|}{ Cell line } & \multicolumn{9}{|c|}{ \%BNC } & \multicolumn{6}{|c|}{ MN/BNC } \\
\cline { 2 - 13 } & 0Gy & 2Gy & 4Gy & 6Gy & 8Gy & 10Gy & 0Gy & 2Gy & 4Gy & 6Gy & 8Gy & $10 \mathrm{~Gy}$ \\
\hline LN-405 & 48.54 & 49.79 & 47.02 & 44.59 & 41.8 & 27.76 & 0.30 & 0.59 & 0.97 & 1.91 & 2.17 & 2.54 \\
\hline 8-MG-BA & 62.5 & 61.45 & 59.11 & 53.81 & 48.36 & 37.17 & 0.18 & 0.45 & 0.71 & 1.26 & 1.51 & 1.73 \\
\hline GAMG & 49.51 & 36.49 & 34.45 & 30 & 32.15 & 24.54 & 0.17 & 0.46 & 0.84 & 1.18 & 1.44 & 1.44 \\
\hline DK-MG & 17.53 & 15.83 & 15.31 & 15.3 & 15.43 & 13.6 & 0.61 & 0.78 & 0.87 & 0.91 & 1.09 & 1.39 \\
\hline DBTRG-05-MG & 8.13 & 8.42 & 8.15 & 8.57 & 7.6 & 7.7 & 0.17 & 0.30 & 0.46 & 0.50 & 0.49 & 0.48 \\
\hline GOS-3 & 19.03 & 15.96 & 9.63 & 9.47 & 8.37 & 9.3 & 0.25 & 0.34 & 0.54 & 0.52 & 0.70 & 0.80 \\
\hline 42-MG-BA & 13.8 & 14.3 & 13.41 & 12.07 & 10.81 & 11.16 & 0.36 & 0.31 & 0.42 & 0.39 & 0.53 & 1.41 \\
\hline U-138-MG & 28.76 & 26.45 & 26.93 & 19.53 & 16.25 & 13.31 & 0.36 & 0.36 & 0.70 & 0.66 & 0.70 & 0.75 \\
\hline
\end{tabular}

\%BNC: percentage of binucleated cells; MN/BNC: absolute values of micronuclei per binucleated cell ratio

\section{STATISTICAL ANALYSIS}

The correlation between radiosensitivity of cell lines (expressed as a normalized $\mathrm{MN} / \mathrm{BNC}$ ratio) and the proliferation fraction (expressed as a $\% \mathrm{BNC}$ in non-irradiated controls) was evaluated using the nonparametric Spearman's rank correlation coefficient. Variation of the $\mathrm{MN} / \mathrm{BNC}$ ratio measurements was measured with the coefficient of variation $(\mathrm{CV})$ :

$$
\mathrm{CV}=\frac{\mathrm{SD}}{\overline{\mathrm{x}}} \times 100 \%
$$

SD: standard deviation; $\bar{X}$ : the mean

Inter- and intra-tumour, as well as inter- and intra-observer variations were estimated using one- way ANOVA test and Spearman's rank correlation coefficient. The means were compared with U MannWhitney test. The level of significance was set to $\mathrm{P}<0.05$.

\section{RESULTS}

The MN/BNC ratio in non-irradiated and irradiated cells is presented in Table 1. For better visualization of percentage increment in $\mathrm{MN}$ frequency after irradiation the baseline values were subtracted (normalized MN/BNC) (Fig. 1). The CBMN assay with DAPI staining provided satisfactory preparations, enabling reliable identification and scoring of $\mathrm{MN}$ (Fig. 2). 


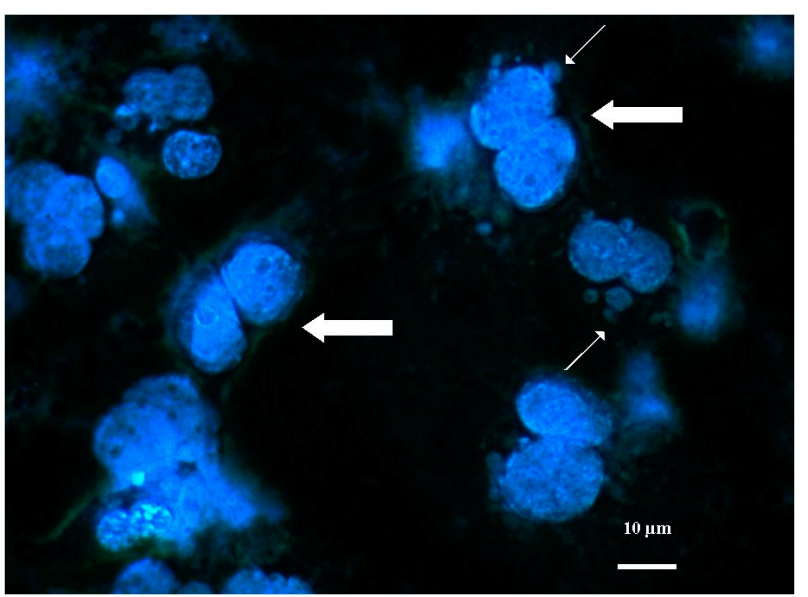

Fig. 2. 8-MG-BA cell line after 10 Gy exposure. Numerous binucleated cells (large arrows) containing multiple micronuclei (small arrows). The micronuclei have a similar structure and intensity to the main nuclei. DAPI stain. Fluorescent microscopy. Original magn. $\times 200$.

The examined glioma cell lines showed high heterogeneity in respect to genotoxic effects of ionizing radiation, as quantified with CBMN assay. Generally, a dose-dependent increase of MN frequency was observed. The majority of cell lines, excluding LN-405, 8-MG-BA and GAMG (arbitrarily labeled radiosensitive) proved to be highly radioresistant (Fig. 1).

The number of spontaneous $\mathrm{MN} / \mathrm{BNC}$ ranged from 0.17 to 0.613 (mean: $0.30 \pm 0.15$ ). After irradiation the increment of $\mathrm{MN} / \mathrm{BNC}$ ratio (i.e., normalized $\mathrm{MN} / \mathrm{BNC}$ ) in the range of $0.312-2.241$ (mean: $0.98 \pm 0.68$ ) was seen at a dose of $10 \mathrm{~Gy}$. A synchronous dose-dependent decrease in \% BNC was seen due to radiation-induced cell cycle delay (Table 1). However, there was a high correlation between $\% \mathrm{BNC}$ in non-irradiated controls and $\mathrm{MN} / \mathrm{BNC}$ ratio in irradiated cells (Spearman's $\mathrm{R}$ range: $0.55-0.85$, significant at 6 Gy $(\mathrm{P}=0.010)$ and $8 \mathrm{~Gy}(\mathrm{P}=0.007))$ (Fig. 3). The radiosensitive and radioresistant lines were discriminated by each normalized $\mathrm{MN} / \mathrm{BNC}$ and $\% \mathrm{BNC}$ value as well as by absolute $\mathrm{MN} / \mathrm{BNC}$ values after 6,8 and 10 Gy doses $(p=0.025)$. The coefficient of variation of three consecutive $\mathrm{MN} / \mathrm{BNC}$ values obtained in a single cell culture at a given irradiation dose ranged from $11.32 \%$ to $23.91 \%$ (mean: $15.48 \%$ ). For comparison, $\mathrm{CV}$ of scorings performed at a given dose in a total of 8 cell lines ranged from $37.8 \%$ to 68.6\% (mean: 54.95\%). The intra-tumour and intertumour mean $\mathrm{CV}$ differed significantly $(\mathrm{P}<0.0001$, one-way ANOVA). In GOS-3 glioma cell line the $\mathrm{MN} / \mathrm{BNC}$ ratio was scored independently by two observers. There was no significant difference between the two series of measurements $(\mathrm{P}=0.97$, one-way ANOVA) (Fig. 4). The mean MN/BNC in 18 consecutive measurements performed in this culture by the two observers was nearly identical $(0.525$ vs. 0.530$)$.

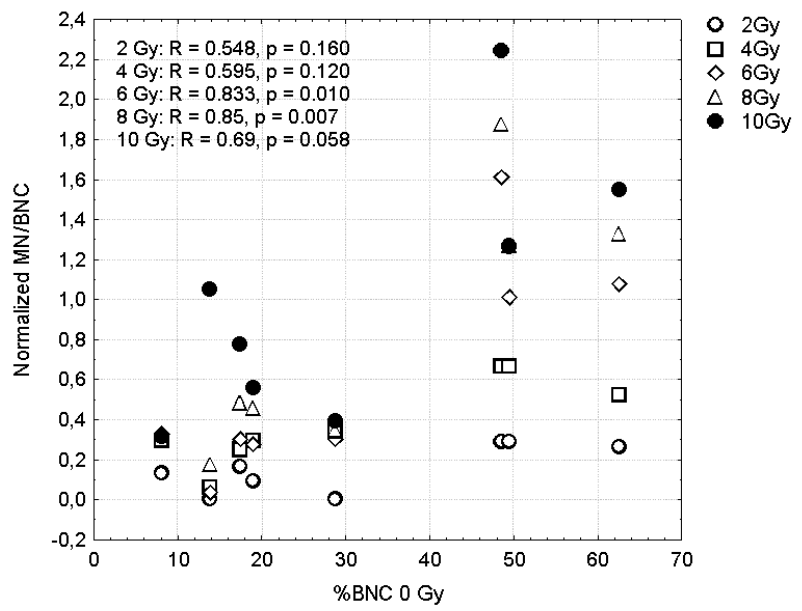

Fig. 3. A scatterplot of normalized micronucleus frequency $(M N / B N C)$ after 2, 4, 6, 8, and $10 G y$ irradiation vs percentage of binucleated cells (\%BNC) in non irradiated controls.

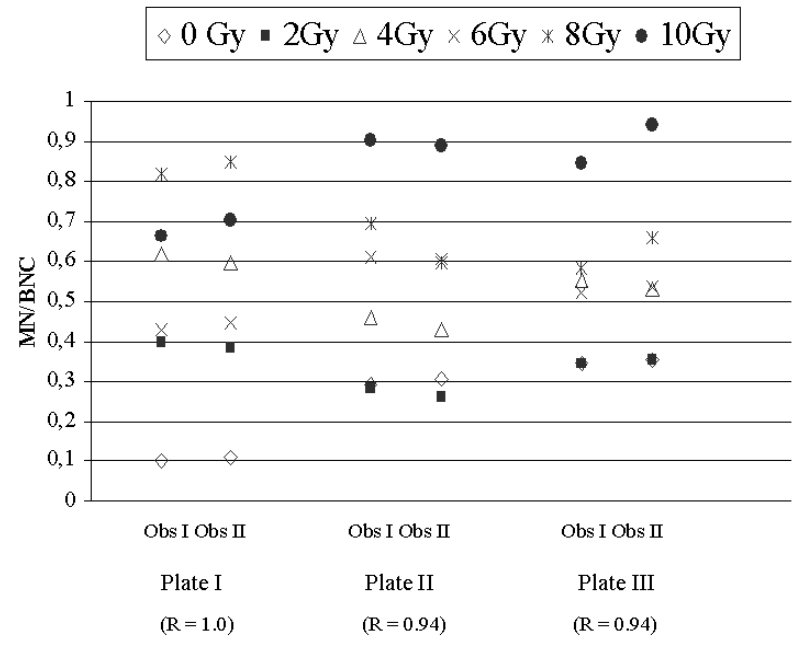

Fig. 4. A scatterplot of absolute values of micronucleus frequencies (MN/BNC) scored by two observers (Obs I and Obs II) on three consecutive plates in GOS-3 line. $R$ - Spearman's coefficient of correlation. High inter-observer reproducibility is confirmed. 


\section{DISCUSSION}

In the present study, the background and radiationinduced DNA damage was measured with the micronucleus assay. Cytokinesis block used in the assay enables accurate evaluation of MN generation after exposure, since cells undergoing mitosis at the time of irradiation (i.e., cells potentially generating micronuclei) are easily identified as binucleated cells (Shibamoto et al., 1991; Fuhrmann et al., 1992; Fenech, 2000). The main advantages of CBMN assay are relative rapidity and simplicity, especially as compared with clonogenic assay, measuring the ability of tumour cells to produce a colony of descendants (Steel, 1993; Widel et al., 1997). The micronucleus assay does not require the clonogenicity of cells.

In the analysis of intra-tumour and inter-tumour variability of $\mathrm{MN} / \mathrm{BNC}$ the estimated $\mathrm{CV}$ differed significantly. This finding confirms applicability of CBMN assay for measurement of cellular radiosensitivity in glioma cells in vitro. In our opinion following the strict criteria for scoring of $\mathrm{MN}$ guarantees high reproducibility of the results (interobserver variation). Simultaneous use of phase contrast microscopy enables more accurate definition of cell borders, reducing the risk of MN misinterpretation (Fig. 5).
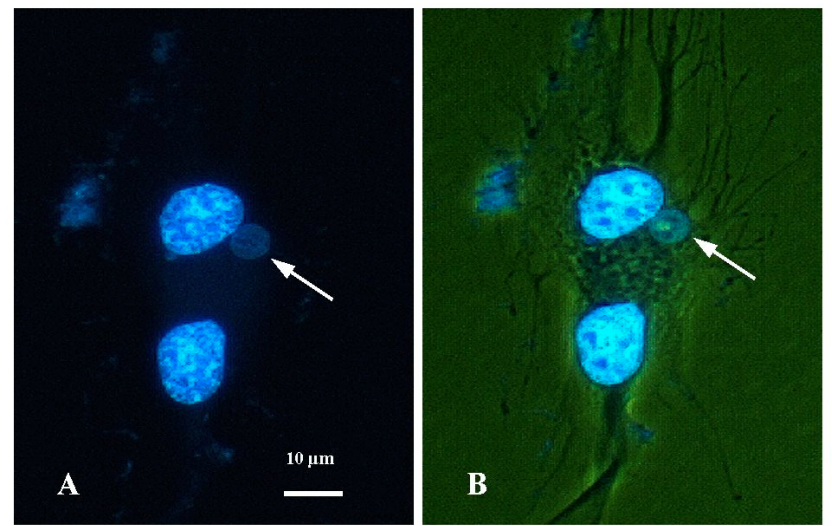

Fig. 5. GOS-3 cell line after 6 Gy exposure. Large micronucleus is seen within binucleated cell (arrow). Binucleation, not clear in fluorescent microscope (A) becomes evident after application of phase contrast equipment (B). DAPI stain. Fluorescent - phase contrast microscopy.

Automated scoring of $\mathrm{MN}$ by computerized image analysis systems is an interesting alternative to tedious manual scoring. It gives results comparable to those obtained by manual scoring (Castelain et al., 1993, Verhaegen et al., 1994) with even better reproducibility (Thierens et al., 1997). However, automated $\mathrm{MN}$ scoring is time-consuming and is thus applicable only to a limited number of slides (Thierens et al., 1997). The studies on automated MN scoring were mostly performed on normal lymphocytes (Castelain et al., 1993; Szirmai et al., 1993, Verhaegen et al., 1994), i.e., cells with relatively uniform morphology as compared to highly pleomorphic cells of human gliomas. Probably, the developing of an appropriate algorithm for automated $\mathrm{MN}$ scoring in cultured gliomas would be a very demanding task. Flow cytometric analysis was also used for MN scoring. The main disadvantage of this approach is that apoptotic cells and apoptotic bodies, if present, can influence MN measurement (Nüsse and Marx, 1997). It would probably be a significant obstacle in analysis of irradiated gliomas, as in the studied cell lines the apoptotic index reached over $10 \%$ in 4 of 8 lines (data not shown).

Analysis of the slides prepared for MN scoring provides additional data regarding cellular kinetics and survival. For example, \%BNC and nuclear division index, based on the ratio of mononucleated, bi- and multinucleated cells reflect proliferative activity (Keshava et al., 1996; Widel et al., 1997; Fenech et al., 2003; Palyvoda et al., 2003), (Fig. 6). In our study we found a high correlation between $\% \mathrm{BNC}$ and normalized $\mathrm{MN} / \mathrm{BNC}$ ratio that suggests greater radiosensitivity in rapidly proliferating cells. The correlation between \%BNC and MN frequency could also be explained by a lower apoptotic rate in rapidly dividing cells. However, the mean apoptotic index in rapidly proliferating lines (LN-405, 8-MGBA, GAMG) was not significantly lower than in other lines (data not shown).

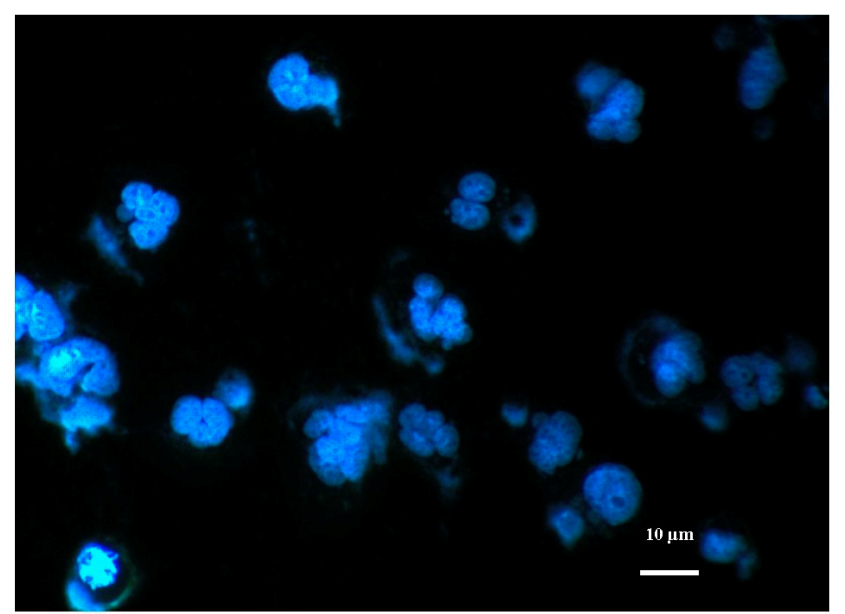

Fig. 6. LN-405 cell line after 2 Gy exposure. Numerous multinucleated cells suggest high proliferative activity (nuclear division index). DAPI stain. Fluorescent microscopy. 
The nucleoplasmic bridge frequency in BNC can be used as a biomarker of chromosome rearrangement (Fenech, 2000). Furthermore, apoptotic index can be measured on the same slides as well (Falkvoll, 1990; Abend et al., 2000) (Fig. 7).

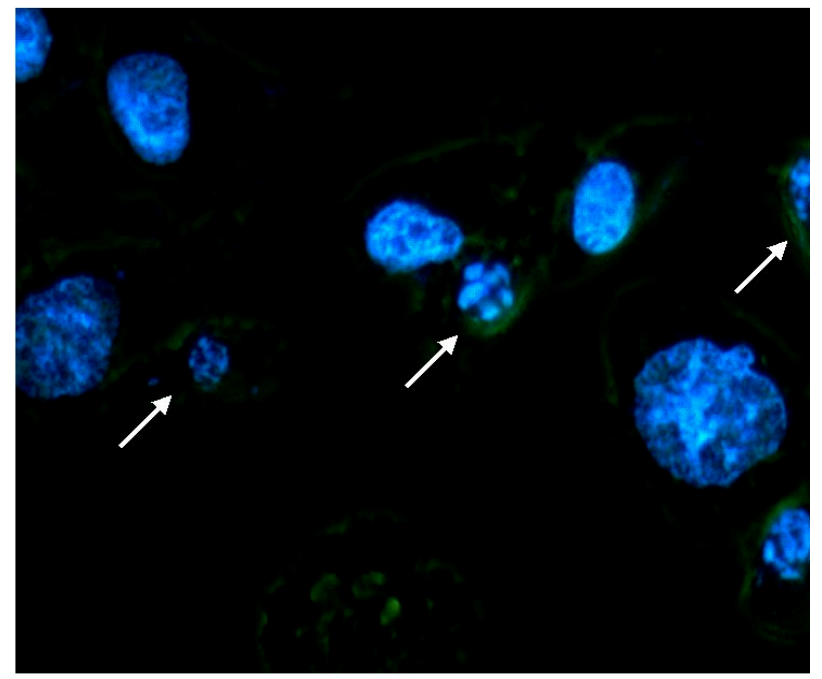

Fig. 7. DK-MG cell line after 10 Gy exposure. Numerous mononucleated apoptotic cells showing condensed chromatin and early nuclear fragmentation (arrows). DAPI stain. Fluorescent - phase contrast microscopy.

It is assumed that frequency of $\mathrm{MN}$ is a reliable marker of cellular radiosensitivity (Wandl et al., 1989; Shibamoto et al., 1991; Mariya et al., 1997), although some authors do not agree with this assumption (Bush and McMillan, 1993; Akudugu et al., 2000). Generally, increase in micronucleus frequency after irradiation is indicative of better response to radiotherapy (Zölzer et al., 1995). MN assay is also used for retrospective dosimetry after exposure to ionizing radiation (Streffer et al., 1998), for biological monitoring of populations exposed to mutagenic and carcinogenic agents (Fenech, 2000) and for quantification of DNA damage/repair processes (Palyvoda et al., 2003).

There are many potential research applications of the described test. For example, we have used the CBMN assay for evaluating radioprotective properties of histone proteins and the relation between cellular proliferation (evaluated by in situ hybridization for histone mRNA) and radioresistance (Slowinski et al., 2003a,b).

\section{ACKNOWLEDGEMENTS}

This work was supported by grant 6P05B 10620 from the State Committee of Scientific Research (KBN, Poland).

\section{REFERENCES}

Abend M, Kehe K, Kehe K, Riedel M, Van Beuningen D (2000). Correlation of micronucleus and apoptosis assay with reproductive cell death can be improved by considering other modes of death. Int J Radiat Biol 76:249-59.

Akudugu JM, Slabbert JP, Serafin A, Bohm L (2000). Frequency of radiation-induced micronuclei in neuronal cells does not correlate with clonogenic survival. Radiat Res 153:62-7.

Bush C, McMillan TJ (1993). Micronucleus formation in human tumour cells: Lack of correlation with radiosensitivity. Br J Cancer 67:102-6.

Castelain P, Van Hummelen P, Deleener A, KirschVolders M (1993). Automated detection of cytochalasin-B blocked binucleated lymphocytes for scoring micronuclei. Mutagenesis 8:285-3.

Countryman PI, Heddle JA (1976). The production of micronuclei from chromosome aberrations in irradiated cultures of human lymphocytes. Mutat Res 41:321-32.

Drexler HG, Dirks W, MacLeod RAF, Quentmeier H, Steube KG, Uphoff CC (eds) (2001). DSMZ catalogue of human and animal cell lines. Eighth edition, Braunschweig.

Falkvoll KH (1990). The occurrence of apoptosis, abnormal mitoses, cells dying in mitosis and micronuclei in a human melanoma xenograft exposed to single dose irradiation. Strahlenther Onkol 166:487-92.

Fenech M (2000). The in vitro micronucleus technique. Mutat Res 455:81-95.

Fenech M, Chang WP, Kirsch-Volders M, Holland N, Bonassi S, Zeiger E (2003). HUMN project: detailed description of the scoring criteria for the cytokinesisblock micronucleus assay using isolated human lymphocyte cultures. Mutat Res 534:65-75.

Fenech M, Morley AA (1985). Measurement of micronuclei in lymphocytes. Mutat Res 147:29-36.

Fenech M, Morley AA (1986). Cytokinesis-block micronucleus method in human lymphocytes: effect of in vivo aging and low dose $\mathrm{X}$ irradiation. Mutat Res 161:193-8.

Fuhrmann C, Streffer C, Müller W-U, Becker U (1992). Micronucleus assay prediction and application optimized by cytochalasin B-induced binucleated tumor cells. Strahlenther Onkol 168:603-9.

Keshava C, Nagalakshmi R, Ong T, Nath J (1996). Inhibitory effect of folinic acid on radiation-induced micronuclei and chromosomal aberrations in V79 cells. Mutat Res 352:123-34.

Mariya YC, Streffer C, Fuhrmann C, Wojcik A (1997). Correlation of radiation-induced micronucleus frequency with clonogenic survival in cell lines of the same origin. Radiat Res 147:29-34.

Nüsse M, Marx K (1997). Flow cytometric analysis of micronuclei in cell cultures and human lymphocytes: advantages and disadvantages. Mutat Res 392:109-15. 
Palyvoda O, Polanska J, Wygoda A, Rzeszowska-Wolny (2003). DNA damage and repair in lymphocytes of normal individuals and cancer patients: studies by the comet assay and micronucleus assay. Acta Biochim Pol 50:181-90.

Schmid W (1975). The micronucleus test. Mutat Res 31:9-15.

Shibamoto Y, Streffer C, Fuhrmann C, Budach V (1991). Tumor radiosensitivity prediction by the cytokinesisblock micronucleus assay. Radiat Res 128:293-300.

Slowinski J, Bierzynska-Macyszyn G, Mazurek U, Glogowska J, Latocha M, Widel M, Mrowka R (2003a). Profile of expression of histone genes differs in radioresistant and radiosensitive human glioma cell lines. Virchows Arch 443:361.

Slowinski J, Bierzynska-Macyszyn G, Widel M, Mazurek U, Latocha M, Mrowka R, Snietura M, Lange D (2003b). Cytokinesis-block micronucleus assay in irradiated human glioma cell lines. Brain Pathol: S 28.

Steel GG (1993). Clonogenic cells and the concept of cell survival. In: Steel GG, ed. Basic clinical radiobiology for radiation oncologists. Ch. 5. London, Edward Arnold, 28-39.

Streffer C, Muller WU, Kryscio A, Bocker W (1998). Micronuclei-biological indicator for retrospective dosimetry after exposure to ionizing radiation. Mutat Res 404:101-5.

Szirmai S, Bérces J, Köteles GJ (1993). Computerized image analysis for determining micronucleus frequency. Environ Health Perspect 101(Suppl. 3):57-60.

Thierens H, Vral A, de Scheerder F, dr Ridder L, Tates A (1997). Semi-automated micronucleus scoring in cytokinesis-blocked lymphocytes after irradiation. Int $\mathrm{J}$ Radiat Biol 72:319-24.
Verhaegen F, Vral A, Seuntjens J, Schipper NW, de Ridder L, Thierens H (1994). Scoring of radiation-induced micronuclei in cytokinesis-blocked human lymphocytes by automated image analysis. Cytometry 17:119-27.

Wandl EO, Ono K, Kain R, Herbsthofer T, Heinert G, Hobarth K (1989). Linear correlation between surviving fraction and the micronucleus frequency. Int $\mathrm{J}$ Radiat Biol 56:771-5.

Weissenborn U, Streffer C (1991). Micronuclei with kinetochores in human melanoma cells and rectal carcinomas. Int J Radiat Biol 59:373-83.

Widel M, Dobrut M, Maka B, Lubecka B, Pluciennik A (1997). The radiosensitivity of human malignant melanomas evaluated by cytokinesis-block micronucleus assay. Neoplasma 44:109-16.

Widel M, Jedrus S, Lukaszczyk B, Raczek-Zwierzycka K, Swierniak A (2003). Radiation-induced micronucleus frequency in peripheral blood lymphocytes is correlated with normal tissue damage in patients with cervical carcinoma undergoing radiotherapy. Radiat Res 159: 713-21.

Widel M, Kolosza Z, Jedrus S, Lukaszczyk B, RaczekZwierzycka K, Swierniak A (2001). Micronucleus assay in vivo provides significant prognostic information in human cervical carcinoma; the updated analysis. Int J Radiat Biol 77:631-6.

Zölzer F, Alberti W, Pelzer T, Lamberti G, Hülskamp FH, Streffer C (1995). Changes in S-phase fraction and micronucleus frequency as prognostic factors in radiotherapy of cervical carcinoma. Radiother Oncol $36: 128-32$. 